\title{
Trace Elements in Gluten-free Pastas and Flours from Markets Located in the Las Vegas, Nevada Area
}

\author{
Christopher J. Collumb ${ }^{1}$, Adam A. Delelegn ${ }^{1}$, Giavanna M. Fernandez ${ }^{2}$, Amanda C. Hudson ${ }^{2}$, Kendra W. \\ Kimberley ${ }^{1}$, Douglas B. Sims ${ }^{2} \&$ Douglas J. Walton ${ }^{2}$ \\ ${ }^{1}$ Department of Biological Sciences, College of Southern Nevada, North Las Vegas, NV 89030, USA \\ ${ }^{2}$ Department of Physical Sciences, College of Southern Nevada, Las Vegas, NV 89146, USA \\ Correspondence: Douglas B Sims, Department of Physical Sciences, College of Southern Nevada, North las \\ Vegas, Nevada, 89030, USA. Tel: 1-702-651-4840. E-mail: douglas.sims@csn.edu
}

Received: July 10, 2019

Accepted: July 26, 2019 Online Published: August 14, 2019

doi:10.5539/jfr.v8n5p59

URL: https://doi.org/10.5539/jfr.v8n5p59

\begin{abstract}
The popularity of gluten-free foods has been increasing across the United States and abroad. A significant reason for this trend involves marketing efforts targeted towards individuals seeking to avoid the consequences of celiac disease or a perceived gluten intolerance. Many gluten-free food products originate in regions of the world where irrigation with metal-contaminated waters is common. Calcium, $\mathrm{Fe}, \mathrm{Mg}, \mathrm{Ti}$ and $\mathrm{Zn}$ were detected at various levels across all foods products. Cadmium was detected in $96.8 \%$ of U.S. and $54.5 \%$ of Asian gluten-free foods with gluten containing foods above reported averages $\left(216 \mu \mathrm{g} \mathrm{kg}{ }^{-1} \mathrm{Cd}\right)$; as was $\mathrm{Co}\left(140 \mu \mathrm{g} \mathrm{kg}^{-1}\right)$ in $48.4 \%$ of U.S., $72.7 \%$ of Asian gluten-free foods, and $40 \%$ of the gluten containing foods; $\mathrm{Cr}$ was in $54.8 \%$ of the U.S., $72.5 \%$ of Asian gluten-free foods, and $100 \%$ of gluten containing food products; while $\mathrm{Ca}, \mathrm{Fe}, \mathrm{Mg}, \mathrm{Ti}$ and $\mathrm{Zn}$ were greater than $10,000 \mathrm{\mu g} \mathrm{kg}^{-1}$ with $\mathrm{Ba}, \mathrm{Cd}, \mathrm{Co}, \mathrm{Mo}$, and $\mathrm{Ni}$ above reported averages. Finally, trace metals were more commonly detected in the gluten containing foods overall. It was found that trace elements were more commonly found in the gluten containing products; however, none of the higher than expected levels pose a significant health risk to consumers.
\end{abstract}

Keywords: gluten-free foods, nutrients, metals, celiac, pasta, flour, Las Vegas

\section{Introduction}

Gluten is a protein found in breads, pastas, and products of wheat, rye, barley, and triticale. According to literature, the proteins glutenin and gliadin are the main products of gluten with gliadin responsible for most of the negative health effects (Basha et al., 2014). Gluten helps food maintain its shape while also binding it together (Basha et al., 2014). For person with a gluten allergy, gluten is known to cause small intestine irritation, among other symptoms, in sufferers of Celiac disease, a genetic based immune disorder (Basha et al., 2014). According to other researchers, celiac disease is characterized by an immune response of the T-lymphocytes in the small intestine to gluten peptide bonds (i.e. Basha et al., 2014, Howdle, 2003, Miedico et al., 2017, Orecchio et al., 2014, Thompson, 1999). While medically debated, many people claim to be gluten sensitive and report allergic response to its protein.

Research suggests that celiac disease occurs in approximately $1 \%$ of the general population (Niewinski, 2008, Thompson, 1999, 2000, Thompson et al., 2005). In addition to sufferers of celiac disease, many people avoid gluten because of a wheat allergy or they believe they have a gluten intolerance, despite there being limited medical evidence that such a medical disorder exists (Elli et al., 2015, Catassi et al., 2013). Current studies indicate that celiac disease is increasing across all age groups, especially in the senior population (Curiel et al., 2014). The only currently available treatment to this disease is a strict gluten-free diet, which can lead to the restoration of the atrophied intestinal villi (Curiel et al., 2014, Niewski, 2008).

The consumption and/or baking with gluten-free products have become much more prevalent due to product availability (Orecchio et al., 2014). Gluten-free consumers can purchase premade gluten-free products such as breads, pastas, flour, and desserts. Today, many foods contain gluten-free starch and flour made of corn, potato, tapioca, or rice. Gluten-free baking mixes and flours are becoming accessible to consumers so that they can bake their own breads, pastas, cake, and other foods, which in turn alleviates the need for them to consume a diet 
consisting of mostly raw and green foods (Orecchio et al., 2014).

Trace metals have a vital role in biology and are essential micro-nutrients that play an active role in biochemical functions of living organisms (Miedico et al., 2017, Orecchio et al., 2014). While some metals like Al, $\mathrm{Cr}$, and $\mathrm{Fe}$ are essential to biological functions at low levels, they can be toxic at higher levels. Other metals (i.e. $\mathrm{Cd}, \mathrm{Pb}, \mathrm{Se}$, V) do not occur naturally in the body, and therefore, their presence is usually the result of ingestation from foods. Exposure to such metals can be harmful to human health, especially in children and the elderly who tend to be more sensitive to these toxins (Miedico et al., 2017).

Gluten-free food products may contain higher and lower levels of trace metals depending on the product or where they are grown in the world (Orecchio et al., 2014, Thompson et al., 2005). Studies have identified that Cd-contaminated wastewater from industrial sites have been used in Asia's agricultural fields (Takagi et al., 2004, Vahter et al., 2007, Yamagami et al., 2006). Consuming foods containing Cd over a lifetime can result in a mild to severe mitochondrial dysfunction called Itai-itai disease (Vahter et al., 2007, Yamagami et al., 2006, Inaba et al., 2006). Extended intake of certain pollutants (i.e. I, $\mathrm{Pb}, \mathrm{As}, \mathrm{Cd}, \mathrm{Hg}$ ) can lead to other disorders in the gastrointestinal tract. The World Health Organization has determined acceptable levels of trace metals in food in cooperation with other international authorities for the protection of human and environmental health (Yamagami et al., 2006, Inaba eta al., 2006).

There are several gluten free cereal products that are primary ingredients for these foods such as rice (Oryza sativa), maize (Zea mays), sorghum (Sorghum bicolour), and buckwheat (Fagopyrum esculentum Moench) according to Orecchio et al. (2014). While there is nutritional value in these foods, they are only part of an overall balanced diet. Buckwheat, for instance, is known as a source of protein, amino acid, vitamins, dietary fiber, minerals, and essential trace elements (Orecchio et al., 2014, Howdle, 2003). Buckwheat; however, has lower concentrations of essential metals (Zn, Fe) when compared with wheat (Orecchio et al., 2014, Vahter et al., 2007). Moreover, the grinding processes to turn such products into flour can also alter the nutrient composition of the food product (Thompson, 1999).

Trace metal concentration in mainstream food products has been well studied however, little information exists for gluten-free foods (e.g. Aziz et al., 2015, Orecchio et al., 2014, Ertl and Coessler, 2018, Parra-Orobio et al., 2017). This research measured trace metals, both toxic and non-toxic, in gluten-free foods $(n=42)$, and the daily intake concentrations. A limited number $(\mathrm{n}=5)$ of gluten containing foods were analyzed for comparison. The overall study objectives were to evaluate the levels of trace metals ( $\mathrm{Al}, \mathrm{Ba}, \mathrm{Ca}, \mathrm{Cd}, \mathrm{Co}, \mathrm{Cr}, \mathrm{Cu}, \mathrm{Fe}, \mathrm{Mg}, \mathrm{Mn}, \mathrm{Mo}$, $\mathrm{Ni}, \mathrm{Ti}, \mathrm{Zn}$ ) found in selected gluten-free food products (i.e. pastas, flours) purchased in the Las Vegas, Nevada (U.S.) market. This study will: 1) identify crustal (Al, $\mathrm{Ca}, \mathrm{Fe}, \mathrm{Mg}, \mathrm{Zn}$ ) and toxic trace metals $(\mathrm{Ba}, \mathrm{Cd}, \mathrm{Co}, \mathrm{Cr}, \mathrm{Cu}$, $\mathrm{Mn}, \mathrm{Mo}, \mathrm{Ni}, \mathrm{Ti}$ ) in gluten-free food products; 2) determine the levels of trace metals in specific gluten-free product types; and 3) if possible, evaluate the level of exposure (i.e. chronic exposure) to consumers of these foods in the literature and discuss possible effects due to low-level chronic-long term exposure.

\subsection{Metals in the Food Chain}

It is known that toxic elements in foods can be from both natural and anthropogenic source (Orecchio et al., 2014, Baker et al., 2018). For instance, Oresschi et al. (2014) determined that metal contamination of food products is related to the soils it grows in and rarely the manufacturing (milling) process. Other researchers have examined the uptake of metals (e.g. $\mathrm{Cu}, \mathrm{Ni}, \mathrm{Fe}, \mathrm{Co}, \mathrm{Zn}, \mathrm{U}, \mathrm{Pb}$ ) in vegetation, animal tissues, and the transfer of said metals via the food chain (Miedico et al., 2017, Kipp et al., 2009, Clemente et al., 2005). High levels of Pb tend to be present in broad leaf plants (Elmleaf, Blackberry and Rubus ulmifolius) grown in contaminated soils as documented by Clemente et al. (2005). The bioaccumulation of As, and resulting phytotoxicity, was observed in areas that had several metal-tolerant plant species (e.g., Angophora floribunda, Cassinia laevis, and Chrysocephalum apiculatum) that colonized the periphery of contaminated sites or were irrigated with contaminated waters (Clemente et al., 2005, Han et al., 2006).

It is known that high levels of metals are possible in grasses, melons, coconuts, fruits, and even in rice, corn, and wheat where effluent from factories or mining is utilized for irrigation (Nicholson et al., 2003, Vazquez et al., 2008, Wang et al., 2007). Crops grown in the mining region of the Sierra Madrona Mountains of southern Spain showed higher concentrations of trace metals ( $\mathrm{Pb}, \mathrm{Zn}, \mathrm{Cd}, \mathrm{Cu}, \mathrm{As}$ and $\mathrm{Se}$ ) (Orecchio et al., 2014). It has been reported that higher concentrations of trace metals in vegetation were more prevalent in crops like rice and wheat where irrigation originated from polluted waters (Reglero et al., 2008).

It is known that contaminated crops affect the food chain and ultimately human health (Inaba et al., 2006, Yamagami et al., 2006). Cadmium contaminated wastewater from industrial sites was used for growing rice in Japan and ultimately impacted local health (Takagi et al., 2004, Vahter et al., 2007). Studies found that residents 
in the area who consumed $3.1 \mathrm{~g}$ to $3.8 \mathrm{~g}$ of $\mathrm{Cd}$ in rice over a lifetime developed mild to severe mitochondrial dysfunction called Itai-itai disease (Inaba et al., 2006). The source of this disease was found to be the direct result of Cd-enriched wastewater discharged to local rivers, and subsequently used in the rice fields. The bioaccumulation of $\mathrm{Cd}$ in the tissue of local residents affected their tubular epithelial cells after 80-weeks of exposure by ingestion of the contaminated rice (Nation Academy of Science [NAS], 1973).

\section{Materials and Methods}

Forty-two (42) samples of gluten-free foods (pastas, flours) and five (5) gluten containing foods (pastas) were purchased in Las Vegas markets in June 2018. Products ("samples") were representative of what is available in the Las Vegas Valley with 31 samples manufactured in the U.S. and eleven (11) imported from Asia. The five (5) gluten containing samples were manufactured in the United States (U.S.). While manufacturing location was known, the agricultural source of the plant material was not. Each sample was homogenized with an acid washed mortar and pestle, immediately sub-sampled and digested with hot aqua-regia acid to reduce degradation. All gluten-free samples were prepared in triplicate, digested, and analyzed per USEPA methods as described below. Data was evaluated for standard deviation $(\sigma)$, mean $(\bar{x})$, minimum $(\mathrm{min})$, and maximum (max) values seeking patterns within each group of products (i.e. gluten free vs. gluten containing) and across groups.

\subsection{Sample Preparation and Analysis}

Forty-two gluten-free and 5 gluten containing samples $(n=47)$ were purchased from local markets and analyzed for trace metals (Al, Ba, Ca, Cd, Co, Cr, Cu, Fe, Mg, Mn, Mo, Ni, Ti, Zn). Approximately $1.0 \mathrm{~g}( \pm 0.001 \mathrm{~g})$ of homogenized food material (gluten-free [e.g. rice, corn] and gluten containing [i.e. wheat]) was processed according to USEPA Solid Waste 846 (SW-846) protocols, including quality control (USEPA, 1997). Fourteen trace elements ( $\mathrm{Al}, \mathrm{Ba}, \mathrm{Ca}, \mathrm{Cd}, \mathrm{Co}, \mathrm{Cr}, \mathrm{Cu}, \mathrm{Fe}, \mathrm{Mg}, \mathrm{Mn}, \mathrm{Mo}, \mathrm{Ni}, \mathrm{Ti}, \mathrm{Zn}$ ) were extracted using USEPA method 3050B (hot aqua-regia acid digestion) followed by USEPA method 6010B for inductively coupled plasma-optical emission spectrometer (USEPA, 1997). Instrument calibration consisted of 6 points across a concentration range (including a blank) and fitted by linear regression with $>0.995 \mathrm{R}^{2}$ (USEPA, 1997). Instrument integrity was verified with a certified reference sample purchased from a USEPA certified supplier with the sample falling within certified windows in order to meet requirements. Samples were analyzed in triplicate with a required relative standard deviation (RSD) of less than $20 \%$ to qualify as acceptable (USEPA, 1997). Method detection limits (MDL) are defined as 3 time the standard deviation $(\sigma)$, where the level of the analyte approaches zero (0). Limit of quantitation (LOQ) is defined as 10 times $\sigma$ with an uncertainty of $\sim 30 \%$ at the $95 \%$ confidence level.

\section{Results and Discussion}

Trace metal concentrations (Al, Ba, Ca, Cd, Co, Cr, Cu, Fe, Mg, Mn, Mo, Ni, Ti, Zn) for 42 gluten-free and 5 gluten containing food samples $(\mathrm{n}=47)$ are presented in Table 1 and reported in $\mu \mathrm{g} \mathrm{kg}^{-1}$, dry weight. Table 2 shows statistics for all of the data in three separate formats; overall data, U.S. gluten free, Asian gluten free, and gluten containing foods of pasta and flour. Samples were processed in triplicate utilizing USEPA quality control measures for accuracy and averaged for reporting purposes. Aluminum was detected at 400 to $6750 \mu \mathrm{g} \mathrm{kg}^{-1}$ (mean $(\overline{\mathrm{x}})$ of 1754) across all products with a U.S. market gluten-free foods $\overline{\mathrm{x}}$ of $1708 \mu \mathrm{g} \mathrm{kg}^{-1}$. Asian gluten-free foods were 550 to $3000 \mu \mathrm{g} \mathrm{kg}^{-1}\left(\overline{\mathrm{x}}=1736 \mu \mathrm{g} \mathrm{kg}^{-1}\right)$ while gluten containing foods ranged between 1450 and 3350 $\mu \mathrm{g} \mathrm{kg}^{-1}\left(\overline{\mathrm{x}}=2080 \mu \mathrm{g} \mathrm{kg}^{-1}\right)$. U.S. market foods were highest in samples $7\left(6750 \mu \mathrm{g} \mathrm{kg}^{-1}\right.$ [pasta] $)$ and $23(5900 \mu \mathrm{g}$ $\mathrm{kg}^{-1}$ [flour]). Asian foods were highest in samples 45 and 47 measuring 2150 and $3350 \mathrm{\mu g} \mathrm{kg}^{-1} \mathrm{Al}$, respectively, with 850 to $3.8 \times 10^{4} \mathrm{\mu g} \mathrm{kg}^{-1}$ reported by other authors (Loska and Wiechuya, 2003, Yokel et al., 2005). 
Table 1. Data covering overall pasta and flour product data set: United States Market, Asian Market, and Gluten foods

\begin{tabular}{|c|c|c|c|c|c|c|c|c|c|c|c|c|c|c|c|c|}
\hline Source & Type & ID & Al & Ba & Ca & Cd & Co & $\mathrm{Cr}$ & $\mathrm{Cu}$ & $\mathbf{F e}$ & Mg & Mn & Mo & $\mathbf{N i}$ & $\mathbf{T i}$ & $\mathbf{Z n}$ \\
\hline US market & Pasta-r & 1 & 1400 & 600 & 375400 & 150 & - & - & 600 & 100 & 13250 & 400 & - & 200 & 30200 & 5950 \\
\hline US market & Pasta-r & 2 & 1950 & 1750 & 332300 & 200 & 150 & 100 & 7300 & 39600 & 739000 & 20850 & 4600 & 1000 & 36950 & 57100 \\
\hline US market & Pasta-r & 3 & 2800 & 2650 & 198200 & 250 & - & 200 & 3500 & 27450 & 842500 & 43300 & 1050 & 500 & 96350 & 54600 \\
\hline US market & Pasta-r & 4 & 550 & 1200 & 109400 & 150 & 150 & 150 & 2500 & 9250 & 804000 & 58100 & 900 & 300 & 13650 & 43250 \\
\hline US market & Pasta-r & 5 & 1050 & 3600 & 274750 & 400 & 150 & 550 & 7500 & 54300 & 756500 & 25750 & 6100 & 3600 & 30800 & 70000 \\
\hline US market & pasta-r & 6 & 2350 & 1950 & 453050 & 350 & 200 & 200 & 6650 & 42750 & 864500 & 35050 & 2650 & 750 & 54200 & 75350 \\
\hline US market & Pasta-r & 7 & 6750 & 2800 & 618500 & 200 & 250 & 200 & 3150 & 26700 & 704500 & 32950 & 400 & 500 & 124000 & 40300 \\
\hline US market & Pasta-r & 8 & 700 & 1150 & 82650 & 300 & - & - & 2050 & 6850 & 631000 & 46700 & 1000 & 350 & 20250 & 36100 \\
\hline US market & Flour-r & 9 & 550 & 750 & 303250 & 200 & - & 550 & 18500 & 57100 & 1817500 & 83100 & 450 & 4050 & 14800 & 64250 \\
\hline US market & Flour-r & 10 & 400 & 1450 & 253700 & - & - & - & - & - & 28950 & 1050 & - & 150 & 7000 & 5750 \\
\hline US market & Flour-r & 11 & 600 & 1100 & 273200 & 250 & 300 & 400 & 22550 & 63200 & 1871000 & 74600 & 750 & 1850 & 82600 & 79550 \\
\hline US market & Flour-r & 12 & 850 & 1550 & 455900 & 150 & - & - & 1250 & 14750 & 258050 & 1900 & 1200 & 600 & 35200 & 13300 \\
\hline US market & Flour-r & 13 & 650 & 600 & 402200 & 150 & - & 100 & 2900 & 1650 & 974610 & 2850 & 250 & 150 & 32500 & 15750 \\
\hline US market & Pasta-r & 14 & 2950 & 7100 & 856000 & 200 & 400 & 200 & 7650 & 46800 & 984000 & 63300 & 1650 & 3850 & 162400 & 77150 \\
\hline US market & Pasta-r & 15 & 2150 & 1300 & 246300 & 200 & 300 & - & 7100 & 39800 & 669000 & 25000 & 1350 & 1800 & 57550 & 69550 \\
\hline US market & Pasta-r & 16 & 400 & 650 & 42400 & 350 & - & - & 750 & 7400 & 202000 & 3000 & 500 & 550 & 51700 & 14500 \\
\hline US market & Pasta-r & 17 & 950 & 1900 & 104300 & 300 & 300 & - & 1950 & 7250 & 365550 & 22800 & 900 & 400 & 24450 & 38950 \\
\hline US market & Pasta-r & 18 & 2050 & 1650 & 176700 & 350 & 150 & 200 & 3150 & 28650 & 1223000 & 79900 & 850 & 1000 & 42200 & 52400 \\
\hline US market & Pasta-r & 19 & 1050 & 6800 & 277050 & 150 & - & - & 1950 & 7200 & 312600 & 13150 & 600 & 950 & 22700 & 24000 \\
\hline US market & Pasta-r & 20 & 1150 & 1600 & 128650 & 250 & - & - & 2550 & 8700 & 850000 & 54100 & 750 & 250 & 17200 & 47600 \\
\hline US market & Pasta-r & 21 & 1100 & 1750 & 107750 & 400 & - & 200 & 2450 & 9650 & 687000 & 39850 & 1250 & 500 & 50050 & 51850 \\
\hline US market & Pasta-r & 22 & 2550 & 2500 & 237100 & 250 & 250 & - & 7550 & 52100 & 590500 & 19800 & 4500 & 2100 & 59750 & 66400 \\
\hline US market & Flour-r & 23 & 5900 & 12100 & 840000 & 200 & 350 & 150 & 8600 & 49600 & 1138000 & 89500 & 1750 & 4350 & 217800 & 77300 \\
\hline US market & Flour-r & 24 & 1250 & 3450 & 2094500 & 250 & 250 & 300 & 9700 & 32100 & 1967500 & 36300 & 550 & 800 & 39800 & 66750 \\
\hline US market & Flour-r & 25 & 900 & 500 & 65100 & 300 & - & - & 1800 & - & 158100 & 15100 & 400 & 450 & 24500 & 25800 \\
\hline US market & Flour-r & 26 & 1100 & 1550 & 14300 & 450 & - & 150 & 2350 & 12350 & 614500 & 22050 & 900 & 850 & 120100 & 34800 \\
\hline US market & Flour-r & 27 & 3250 & 800 & 96700 & 600 & 250 & - & 2300 & 34900 & 865000 & 29200 & 1100 & 2300 & 86400 & 50050 \\
\hline US market & Flour-r & 28 & 1950 & 9000 & 1436500 & 300 & 250 & 250 & 13850 & 46000 & 1804500 & 69900 & 300 & 2100 & 55250 & 80400 \\
\hline US market & Flour-r & 29 & 1050 & 650 & 1936000 & 250 & - & - & 1100 & 49200 & 276300 & 26300 & 750 & 300 & 19900 & 25500 \\
\hline US market & Flour-r & 30 & 900 & 950 & 188600 & 200 & - & - & 1200 & 5300 & 370050 & 23500 & 250 & 400 & 24350 & 23350 \\
\hline US market & Flour-r & 31 & 1700 & 1900 & 191600 & 350 & - & 200 & 2250 & 13350 & 593500 & 19400 & 1200 & 900 & 85700 & 37850 \\
\hline Asian Market & Pasta-r & 32 & 950 & 1300 & 65000 & 500 & - & - & 3500 & 3550 & 121550 & 20900 & 900 & 300 & 20200 & 30300 \\
\hline Asian Market & Flour-r & 33 & 650 & 3450 & 336050 & - & 200 & - & 300 & 550 & 56900 & 8550 & 2100 & - & 11100 & 6400 \\
\hline Asian Market & Flour-r & 34 & 2400 & 450 & 137550 & - & 200 & 200 & 3800 & 20450 & 1392500 & 18650 & - & 500 & 8350 & 37900 \\
\hline Asian Market & Flour-r & 35 & 1600 & 1200 & 100800 & 250 & 200 & 650 & 1000 & 2000 & 115300 & 14400 & 1750 & 350 & 30650 & 30550 \\
\hline Asian Market & Pasta-r & 36 & 2150 & 2200 & 118400 & - & 350 & 300 & 1600 & 4050 & 42350 & 4800 & 850 & 2150 & 148650 & 26450 \\
\hline Asian Market & Pasta-r & 37 & 3000 & 4050 & 141650 & 250 & & 400 & 850 & 7200 & 86900 & 3850 & 350 & 1850 & 94850 & 16550 \\
\hline Asian Market & Flour-r & 38 & 950 & 1100 & 145100 & 300 & 200 & 150 & 1300 & 1400 & 129700 & 13000 & - & - & 26450 & 27700 \\
\hline Asian Market & Pasta-r & 39 & 1950 & 350 & 109100 & - & 250 & 1950 & - & 6700 & 31700 & 400 & - & 500 & 24350 & 5350 \\
\hline Asian Market & Pasta-r & 40 & 550 & 650 & 194800 & - & 350 & - & - & & 33300 & - & - & - & 11050 & 6750 \\
\hline Asian Market & Pasta-r & 41 & 2000 & 850 & 84300 & 450 & 450 & 300 & 250 & 2650 & 39550 & 1550 & - & 5600 & 311550 & 10200 \\
\hline Asian Market & Pasta-r & 42 & 2900 & 650 & 115800 & 250 & - & 700 & 300 & 4700 & 25400 & 1000 & - & 5900 & 59350 & 7900 \\
\hline Gluten Foods & Pasta-w & 43 & 1450 & 4750 & 209300 & 250 & - & 1700 & 3700 & 34950 & 433500 & 19850 & 700 & 5350 & 10350 & 28000 \\
\hline Gluten Foods & Pasta-w & 44 & 1600 & 5250 & 207750 & 250 & 200 & 1700 & 3150 & 33650 & 457800 & 15400 & 1050 & 4950 & 22050 & 47850 \\
\hline Gluten Foods & Pasta-w & 45 & 2150 & 9700 & 323100 & 250 & 200 & 1800 & 5000 & 43750 & 1168000 & 48300 & - & 5100 & 22350 & 68050 \\
\hline Gluten Foods & Pasta-w & 46 & 1850 & 5550 & 571500 & 200 & - & 1650 & 6100 & 50200 & 244850 & 15000 & - & - & 22550 & 29300 \\
\hline Gluten Foods & Pasta-w & 47 & 3350 & 3700 & 659000 & 350 & - & 1650 & 3100 & 30800 & 441950 & 18550 & - & 5150 & 36250 & 47450 \\
\hline
\end{tabular}

NOTE: Data is reported in ug $\mathrm{kg}^{-1}$. Sample Identification (ID). When data is less than instrument detection level (IDL), it is represented as a "- “. Sample data to be valid must be above limit of quantitation (LOQ). Statistical data shown is broken into four (4) areas; overall data, United States market gluten free foods (USM), Asian gluten free foods (Asian), and gluten containing foods (control), source of food type: $r=$ rice products, $w=$ wheat products 
Table 2. Statistical data covering overall data set, United States products (USM), Asian products (Asian), and Gluten containing products (Control)

\begin{tabular}{|c|c|c|c|c|c|c|c|c|c|c|c|c|c|c|c|}
\hline Source & Statistical parameter & Al & Ba & $\mathbf{C a}$ & Cd & Co & $\mathrm{Cr}$ & $\mathrm{Cu}$ & $\mathbf{F e}$ & $\mathrm{Mg}$ & Mn & Mo & $\mathbf{N i}$ & $\mathbf{T i}$ & $\mathbf{Z n}$ \\
\hline & $\sigma$ & 1275 & 2628 & 438831 & 101 & 81 & 614 & 4645 & 19507 & 535204 & 24212 & 1286 & 1824 & 58792 & 23223 \\
\hline Overall & $\overline{\mathrm{x}}$ & 1754 & 2606 & 355133 & 278 & 252 & 575 & 4333 & 23651 & 612717 & 27890 & 1294 & 1757 & 55328 & 39407 \\
\hline \multirow[t]{6}{*}{ data } & MIN & 400 & 350 & 14300 & 150 & 150 & 100 & 250 & 100 & 13250 & 400 & 250 & 150 & 7000 & 5350 \\
\hline & MAX & 6750 & 12100 & 2094500 & 600 & 400 & 1950 & 22550 & 63200 & 1967500 & 89500 & 6100 & 5900 & 311550 & 80400 \\
\hline & IDL & 5 & 2 & 5 & 2 & 2 & 2 & 2 & 3 & 5 & 3 & 3 & 3 & 3 & 5 \\
\hline & LOQ & 15 & 6 & 15 & 6 & 6 & 6 & 6 & 10 & 15 & 10 & 10 & 10 & 10 & 15 \\
\hline & & $\mathrm{Al}$ & $\mathrm{Ba}$ & $\mathrm{Ca}$ & $\mathrm{Cd}$ & Co & $\mathrm{Cr}$ & $\mathrm{Cu}$ & $\mathrm{Fe}$ & $\mathrm{Mg}$ & $\mathrm{Mn}$ & Mo & $\mathrm{Ni}$ & $\mathrm{Ti}$ & $\mathrm{Zn}$ \\
\hline & $\sigma$ & 1465 & 2685 & 515270 & 104 & 77 & 136 & 5276 & 19746 & 524697 & 25700 & 1406 & 1234 & 47479 & 23186 \\
\hline \multirow[t]{4}{*}{ USM } & $\overline{\mathrm{x}}$ & 1708 & 2494 & 424905 & 270 & 247 & 241 & 5223 & 27381 & 773434 & 34798 & 1341 & 1221 & 56139 & 45982 \\
\hline & MIN & 400 & 500 & 14300 & 150 & 150 & 100 & 600 & 100 & 13250 & 400 & 250 & 150 & 7000 & 5750 \\
\hline & MAX & 6750 & 12100 & 2094500 & 600 & 400 & 550 & 22550 & 63200 & 1967500 & 89500 & 6100 & 4350 & 217800 & 80400 \\
\hline & $\sigma$ & 867 & 1240 & 73306 & 113 & 96 & 587 & 1342 & 5733 & 401170 & 7578 & 715 & 2335 & 91634 & 12044 \\
\hline \multirow[t]{4}{*}{ Asian } & $\overline{\mathrm{x}}$ & 1736 & 1477 & 140777 & 333 & 275 & 581 & 1433 & 5325 & 188650 & 8710 & 1190 & 2144 & 67868 & 18732 \\
\hline & MIN & 550 & 350 & 65000 & 250 & 200 & 150 & 250 & 550 & 25400 & 400 & 350 & 300 & 8350 & 5350 \\
\hline & MAX & 3000 & 4050 & 336050 & 500 & 450 & 1950 & 3800 & 20450 & 1392500 & 20900 & 2100 & 5900 & 311550 & 37900 \\
\hline & $\sigma$ & 758 & 2296 & 209500 & 55 & - & 61 & 1305 & 8058 & 356646 & 14060 & 247 & 165 & 9175 & 16410 \\
\hline \multirow[t]{3}{*}{ Control } & $\overline{\mathrm{x}}$ & 2080 & 5790 & 394130 & 260 & 200 & 1700 & 4210 & 38670 & 549220 & 23420 & 875 & 5138 & 22710 & 44130 \\
\hline & MIN & 1450 & 3700 & 207750 & 200 & 200 & 1650 & 3100 & 30800 & 244850 & 15000 & 700 & 4950 & 10350 & 28000 \\
\hline & MAX & 3350 & 9700 & 659000 & 350 & 200 & 1800 & 6100 & 50200 & 1168000 & 48300 & 1050 & 5350 & 36250 & 68050 \\
\hline
\end{tabular}

NOTE: Data is reported in ug $\mathrm{kg}^{-1}$. When data is less than instrument detection level (IDL), it is represented as a " - ". Sample data to be valid must be above limit of quantitation (LOQ). Statistical data shown is broken into four (4) areas; overall data, United States market gluten free foods (USM), Asian gluten free foods (Asian), and gluten containing foods (control); mean: $\bar{x}$; standard deviation: $\sigma$

With $\mathrm{Al}$ at a level of $6750 \mu \mathrm{g} \mathrm{kg}-1$, it is important to understand that other studies have established that oral exposure to $\mathrm{Al}$ is not considered harmful as it is poorly absorbed and is excreted through feces and urine (Finberg et al., 1986). It has been reported; however, that ingestion of high amounts of Al can lead to nausea, mouth and skin ulcers, skin rashes, vomiting, diarrhea, and arthritic pain (Jaishankar et al., 2014). These symptoms are generally mild and short lived although people with renal disease, especially children, are at risk of developing Al toxicity (Finberg et al., 1986, Jaishankar et al., 2014). Finally, the Food and Drug Administration (FDA) has determined that aluminum used as food additives, are generally safe; however, they have set an exposure limit for $\mathrm{Al}$ at $0.2 \mathrm{mg} \mathrm{L}^{-1}$ in bottle water according to ATSDR (2008).

Barium was detected at 350 to $1.2 \times 10^{4} \mu \mathrm{g} \mathrm{kg}^{-1}$ across all samples $\left(\overline{\mathrm{x}}=2606 \mu \mathrm{g} \mathrm{kg}{ }^{-1}\right)$. The U.S. gluten-free samples ranged between 500 and $1.2 \times 10^{4} \mu \mathrm{g} \mathrm{kg}^{-1}\left(\overline{\mathrm{x}}=2494 \mu \mathrm{g} \mathrm{kg}^{-1}\right)$ while the Asian samples ranged from 350 to $4050 \mu \mathrm{g} \mathrm{kg}^{-1}$ ( $\overline{\mathrm{x}}=1477 \mu \mathrm{g} \mathrm{kg}^{-1}$ ), and gluten containing foods from 3700 to $9700 \mu \mathrm{g} \mathrm{kg}^{-1}$ ( $\left.\overline{\mathrm{x}}=5790 \mu \mathrm{g} \mathrm{kg}^{-1}\right)$. Literature has shown cereal products (both gluten and gluten-free) tend to encompass higher Ba levels such as bran flakes at $3900 \mu \mathrm{g} \mathrm{kg}^{-1}$ (Mertz, 1986). Current Ba data falls within stated ranges although $11.9 \%$ of samples exceeded Mertz (1986) average in samples 14 (7100 $\left.\mu \mathrm{g} \mathrm{kg}^{-1}\right), 19\left(6800 \mu \mathrm{g} \mathrm{kg}^{-1}\right), 23\left(12100 \mu \mathrm{g} \mathrm{kg}^{-1}\right), 28(9000$ $\left.\mu \mathrm{g} \mathrm{kg}^{-1}\right)$, and $37\left(4050 \mu \mathrm{g} \mathrm{kg}^{-1}\right)$. Data also falls within stated ranges reported by Millour et al. (2012).

Although our findings indicate that the highest level of Ba was detected at $1.2 \times 10^{4} \mathrm{\mu g} \mathrm{kg}^{-1}$, according to the ATSDR (2008), Ba toxicity depends on its solubility in water and bodily fluids. Insoluble barium salts are nontoxic, whereas the barium ion $\left(\mathrm{Ba}^{2+}\right)$ and compounds that can dissolve in water or can be diluted in hydrochloric acid, such as chloride, nitrate, carbonate, and hydroxide, are toxic. The predominant effect of barium toxicity is hypokalemia that can result in ventricular tachycardia, hypertension and/or hypotension, muscle weakness, and paralysis (ATSDR, 2008).

Calcium ranged from $1.4 \times 10^{4}$ to $2.09 \times 10^{6} \mu \mathrm{g} \mathrm{kg}^{-1}$ with an overall $\overline{\mathrm{x}}$ of $3.55 \times 10^{5} \mu \mathrm{g} \mathrm{kg}^{-1}$. Gluten-free products from the U.S. markets ranged between $1.4 \times 10^{4}$ and $2.09 \times 10^{6} \mu \mathrm{g} \mathrm{kg}^{-1}\left(\overline{\mathrm{x}}=4.24 \times 10^{5} \mu \mathrm{g} \mathrm{kg}^{-1}\right)$ while the Asian samples were between $6.5 \times 10^{4}$ and $3.36 \times 10^{5} \mu \mathrm{g} \mathrm{kg}^{-1}\left(\overline{\mathrm{x}}=1.4 \times 10^{5} \mu \mathrm{g} \mathrm{kg}^{-1}\right)$, and gluten containing samples ranged between $2.07 \times 10^{5}$ and $6.5 \times 10^{5} \mu \mathrm{g} \mathrm{kg}^{-1} \mathrm{Ba}\left(\overline{\mathrm{x}}=3.9 \times 10^{5} \mu \mathrm{g} \mathrm{kg}^{-1}\right)$. It has been noted that $\mathrm{Ca}$ in gluten-free foods ranged between 5000 and $1.68 \times 10^{6} \mu_{\mathrm{g} \mathrm{kg}}^{-1}$ and was higher for gluten containing foods (Orecchio et al., 2015). Prolonged exposure to $\mathrm{Ca}$ is a concern as calcification in the kidneys (nephrocalcinosis) can lead to the formation of nephrolithiasis; i.e. kidney stones (Patel and Goldfarb, 2010, Ross et al., 2011). The current study falls above Orecchio et al. (2015) established ranges for the U.S. market gluten-free foods and therefore, may pose an issue with chronic exposure.

Calcium is vital for normal body functions and studies have established that it is difficult for a normal, healthy 
adult to consume excess Ca by diet alone (Patel and Goldfarb, 2010, Ross et al., 2011). If Ca toxicity (e.g. hypercalcemia) is an issue however, signs may include anorexia, weight loss, polyuria, heart arrhythmias, fatigue, and soft tissue calcification (Patel and Goldfarb, 2010). Other authors have found that tissues most at risk of calcification include vascular tissues, lungs, and kidneys. Additionally, calcification of the kidneys (nephrocalcinosis) may lead to the formation of nephrolithiasis (i.e. kidney stones) according to Patel and Goldfarb (2010) and Ross et al. (2011). Studies have established that children under the age of 4 have an Upper Intake Level (UIL) of Ca that various by life stages. For instance, infants 0-6 months in age have an UIL of $1000 \mathrm{mg} /$ day while the UIL in adults $>51$ years is $2000 \mathrm{mg} /$ day (Patel and Goldfarb, 2010, Ross et al., 2011). This study shows that the gluten free and gluten containing have levels far below the mg/day intake that would produce damage.

Cadmium ranged from 150 to $600 \mu \mathrm{g} \mathrm{kg}^{-1}$ with a $\overline{\mathrm{x}}$ of $278 \mu \mathrm{g} \mathrm{kg}-1$ across all products. The U.S. gluten free foods ranged between 150 and $600 \mu \mathrm{g} \mathrm{kg}^{-1}$ ( $\left.\overline{\mathrm{x}}=270 \mu \mathrm{g} \mathrm{kg}^{-1}\right)$, Asian products between 250 to $500 \mu \mathrm{g} \mathrm{kg}^{-1}$ ( $\overline{\mathrm{x}}=333 \mu \mathrm{g}$ $\left.\mathrm{kg}^{-1}\right)$, and gluten containing products between 200 and $350 \mu \mathrm{g} \mathrm{kg}^{-1}\left(\overline{\mathrm{x}}=260 \mathrm{\mu g} \mathrm{kg}^{-1}\right)$. It is worth noting that $45 \%$ of the products from the Asian markets contained no detectable Cd (samples 33, 34, 36, 39, 40). Other studies have established a range for $\mathrm{Cd}$ in plant materials including those used for food stocks to be 2 to $216 \mu \mathrm{g} \mathrm{kg}^{-1}$ (EC, 2006, Skrbic et al., 2013). Many of the samples in this study were above this range. With almost 55\% of U.S. market foods, $36 \%$ of Asian, and $80 \%$ for gluten containing foods above the established range. Moreover, six samples (samples $5,21,26,27,32,41)$ were $1 \sigma$ above the $\bar{x}\left(379 \mu \mathrm{g} \mathrm{kg}^{-1}\right)$ with gluten containing foods falling below.

Data show that gluten free and gluten containing foods have levels far below the $\mathrm{mg} / \mathrm{day}$ for Cd intake that would produce harm. However, it is important to state that other studies indicate that soluble Cd compounds of $\mathrm{SO}_{4}{ }^{2-}$ and $\mathrm{Cl}^{-}$salt forms have been shown to cause both acute and chronic intoxication (Jaishankar et al., 2014, Tchounwou et al., 2012). Moreover, acute cadmium ingestion can cause gastrointestinal irritation leading to GI tract erosion, abdominal pain, burning sensation, nausea, vomiting, salivation, and diarrhea (Jaishankar et al., 2014). It can also cause hepatic, renal, pulmonary damage, and coma. Chronic low-level exposure can cause cadmium to be deposited in the kidneys, leading to renal disease (Tchounwou et al., 2012). Data shows that the consumption of $\mathrm{Cd}$ through gluten-free foods is unlikely according to Inaba et al. (2006) as it would require 3,100 to $3,800 \mu \mathrm{g}$ of $\mathrm{Cd}$ over a lifetime to cause mitochondrial dysfunction disease.

Cobalt (Co) levels ranged from 150 to $400 \mu \mathrm{g} \mathrm{kg}^{-1}\left(\overline{\mathrm{x}}=252 \mu \mathrm{g} \mathrm{kg}{ }^{-1}\right)$ for all products including the U.S. market, Asian, and gluten containing foods. The U.S. market ranged from 150 to $400 \mu \mathrm{g} \mathrm{kg}^{-1}(\overline{\mathrm{x}}=247)$, Asian ranged from 200 to $450 \mu \mathrm{g} \mathrm{kg}^{-1}$ ( $\overline{\mathrm{x}}=275 \mu \mathrm{g} \mathrm{kg}^{-1}$ ), and gluten containing products at $200 \mu \mathrm{g} \mathrm{kg}^{-1}$ for the minimum, maximum and $\overline{\mathrm{x}}$. Within the gluten-free foods (Asian / U.S. market), 4 samples were $1 \sigma$ (i.e. $333 \mu \mathrm{g} \mathrm{kg}^{-1} \mathrm{Co}$ ) above the $\overline{\mathrm{x}}$; (samples 14, 36, 41 [pastas], 23 [flour]). The highest Co was found in Asian gluten-free foods containing 200 to $450 \mu \mathrm{g} \mathrm{kg}^{-1}$ while the U.S. gluten-free foods contain between 200 and $450 \mu \mathrm{g} \mathrm{kg}^{-1}$. Most samples (53.2\%) were within 4 to $140 \mu \mathrm{g} \mathrm{kg}^{-1}$ established by other researchers (Podio et al., 2013).

Cobalt is an essential micronutrient consumed in the form of vitamin $\mathrm{B}_{12}$. While this study indicates that $\mathrm{Cr}$ is at levels low enough as to not pose an acute effect unless a significant amount is consumed (Leyssens et al., 2017). Cobalt toxicity can occur acutely in large doses or cumulatively with long-term low level exposure according to Leyssens et al. (2017) and Simonsen et al. (2012). Water-soluble cobalt salts are rapidly absorbed from the small intestine. Co causes erythropoiesis by increasing erythropoietin production. It is also known for increasing the oxygen-carrying capacity of the blood and therefore enhancing physical endurance (Leyssens et al., 2017, Simonsen et al., 2012). Finally, it is low-level chronic exposure that can pose a toxicity issue to the consumer (Simonsen et al., 2012).

Chromium levels ranged from 100 to $1950 \mu \mathrm{g} \mathrm{kg}^{-1}\left(\overline{\mathrm{x}}=575 \mathrm{\mu g} \mathrm{kg}^{-1}\right.$ ) while the U.S. gluten free ranging between 100 and $550 \mu \mathrm{g} \mathrm{kg}^{-1}$; Asian foods ranged from 150 to $1950 \mu \mathrm{g} \mathrm{kg}^{-1}$ while gluten containing products varied from 1650 to $1800 \mu \mathrm{g} \mathrm{kg}^{-1}$. For Cr, no U.S. gluten-free were above the overall $\overline{\mathrm{x}}$ of $575 \mu \mathrm{g} \mathrm{kg}^{-1}$; however, both the Asian and the gluten containing foods were above this level. Of the Asian and U.S. gluten-free foods, only 1 sample of a flour product (sample 39) was $1 \sigma$ above the overall $\bar{x}$ (i.e. $575 \mu \mathrm{g} \mathrm{kg}^{-1}$ ). Current results exceed the literature established value by Tchounwou et al. (2012). It is important to point out that the highest $\mathrm{Cr}$ ( $1650-$ $1800 \mu \mathrm{g} \mathrm{kg}^{-1}$ ) detected was in gluten containing products; twice that established in the literature.

The health hazards associated with $\mathrm{Cr}$ depend greatly on its oxidation state. This study considered $\mathrm{Cr}^{3+}$ and not the more harmful $\mathrm{Cr}^{6+}$ due to its reduction to $\mathrm{Cr}^{3+}$ in a relatively short time and therefore, these foods would not contain the more harmful form of $\mathrm{Cr}^{6+}$ (Jaishankar et al., 2014). The most common forms are trivalent $\left(\mathrm{Cr}^{3+}\right)$, a nutrient, and hexavalent $\left(\mathrm{Cr}^{6+}\right)$, a known toxin (Jaishankar et al., 2014). Trivalent (III) $\mathrm{Cr}$ is readily oxidized to 
hexavalent (VI) due to the excess oxygen in the environment. Hexavalent (VI) $\mathrm{Cr}$ is highly water soluble, making it extremely toxic compared to the trivalent (III) form (Jaishankar et al., 2014, Tchounwou et al., 2012). Trivalent $\mathrm{Cr}$ is the typical form found in foods and usually not an issue. However, the uptake of $\mathrm{Cr}^{6+}$ by plants is

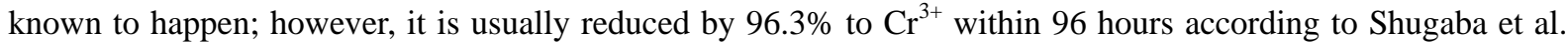
(2012).

Copper in gluten-free foods in U.S. products ranged between 600 and $2.25 \times 10^{4} \mu \mathrm{g} \mathrm{kg}^{-1}$, Asian products ranged from 250 to $3800 \mu \mathrm{g} \mathrm{kg}^{-1}$, and gluten containing foods ranged from 3100 to $6100 \mu \mathrm{g} \mathrm{kg}^{-1}$ with an overall $\overline{\mathrm{x}}$ of $4333 \mu \mathrm{g} \mathrm{kg}^{-1}$. Four samples $(9,11,24,28)$ were $1 \sigma$ above the overall $\overline{\mathrm{x}}$ (i.e. $4333 \mu \mathrm{g} \mathrm{kg}^{-1} \mathrm{Cu}$ ). However, the data is within established ranges (1800 to $1 \times 10^{4} \mathrm{\mu g} \mathrm{kg}^{-1}$ ) according to Ertl and Goessler (2018) and the WHO (2004) maximum per day intake of $1 \times 10^{4} \mathrm{\mu g} \mathrm{kg}^{-1}$ for ages 19 to 70 years. Copper is an essential nutrient as it serves as a co-factor for several oxidative stress-related enzymes (Kahn and Line (2010a, 2010b). It is also involved in the formation of hemoglobin, carbohydrate metabolism, catecholamine biosynthesis, and the formation of cross-links in collagen, elastin, and keratin in the hair (Tchounwou et al., 2012). The maximum exposure to $\mathrm{Cu}$ per day is recommended at $0.5 \mathrm{mg} \mathrm{kg}^{-1}$ according to the ATSDR (2008). Excess exposure to $\mathrm{Cu}$ leads to bioaccumulation in the liver, resulting in chronic hepatitis and cirrhosis according to Kahn and Line (2010a) and Tchounwou et al. (2012).

Iron concentrations in gluten-free products from the U.S. markets ranged from 100 to $6.32 \times 10^{4} \mu \mathrm{g} \mathrm{kg}^{-1}$; Asian foods contained the lowest $\mathrm{Fe}$ (550 to $2.04 \times 10^{4} \mathrm{\mu g} \mathrm{kg}^{-1}$ ); gluten containing foods ranged from $3.08 \times 10^{4}$ to $5.02 \times 10^{4} \mu \mathrm{g} \mathrm{kg}^{-1}$. Data is within the established limits $\left(1.3 \times 10^{4}\right.$ to $\left.1.03 \times 10^{5} \mu \mathrm{g} \mathrm{kg}^{-1}\right)$ for wheat and gluten-free food products as described by Ertl and Goessler (2018). Iron is an important nutrient as it is a vital cofactor for many proteins and enzymes; deficiency can lead to anemia and decreased oxygen delivery to tissues enzymes (Jaishankar et al., 2014, Kahn and Line, 2010b). Studies show that $20 \mathrm{mg} \mathrm{kg-1}$ per day can lead to nausea, vomiting, and stomach pain, especially on low protein diets (Jaishankar et al., 2014).

Magnesium is another important part of a daily diet and vital for healthy functions. Mg however, was detected at $1.32 \times 10^{4}$ to $1.96 \times 10^{6} \mathrm{\mu g} \mathrm{kg}^{-1}$ with an overall $\overline{\mathrm{x}}$ of $6.12 \times 10^{5} \mu \mathrm{g} \mathrm{kg}^{-1}$. U.S. gluten-free foods were within the overall range, Asian products ranged between $2.54 \times 10^{4}$ and $1.39 \times 10^{6} \mu \mathrm{g} \mathrm{kg}^{-1}$ while gluten containing foods were between $2.44 \times 10^{5}$ and $1.16 \times 10^{6} \mu \mathrm{g} \mathrm{kg}^{-1}\left(\overline{\mathrm{x}}=5.49 \times 10^{5} \mu \mathrm{g} \mathrm{kg}^{-1}\right)$. Gluten-free products were $1 \sigma$ above the overall $\overline{\mathrm{x}}$ (i.e. $1.147 \times 10^{6} \mathrm{\mu g} \mathrm{kg}^{-1} \mathrm{Fe}$ ) in $14 \%$ of samples $(9,11,18,24,28,34)$. Findings are comparable with other studies (350 to $1.4 \times 10^{4} \mu \mathrm{g} \mathrm{kg}^{-1}$ ) as provided by Podio et al. (2013). The risk of magnesium toxicity is increased in individuals with decreased renal function or with renal failure as the kidney is responsible for removing excess magnesium from the body (Higdon et al., 2014). The Food and Nutrition Board (FNB) Institute of Medicine (1997), and Ertl and Goessler (2004) state that consuming $3 \times 10^{5}$ and $4.2 \times 10^{5}$ per day is healthy and therefore, findings are within established norms.

Manganese detected in U.S. foods ranged from 400 to $8.95 \times 10^{4} \mu \mathrm{g} \mathrm{kg}^{-1}$ with an overall $\overline{\mathrm{x}}$ of $2.78 \times 10^{4} \mathrm{\mu g} \mathrm{kg}^{-1}$. Asian foods ranged from 400 to $2.09 \times 10^{4} \mu_{\mathrm{g} \mathrm{kg}} \mathrm{kg}^{-1}$ while gluten samples ranged from $1.5 \times 10^{4}$ to $4.83 \times 10^{4} \mu \mathrm{g}$ $\mathrm{kg}^{-} 1$. Samples contained $\mathrm{Mn}$ at $1 \sigma$ above the overall $\overline{\mathrm{x}}$ in $14 \%$ of the gluten-free samples $(9,11,18,24,28,34$, and 45). Manganese is an essential nutrient, but can have toxic consequences if too much is ingested. The primary oral route for intoxication is through contaminated water as its bioavailability is higher in water (Higdon et al., 2014). The risk of manganese neurotoxicity is set at $2 \mathrm{mg} /$ day for children $1-3$ years; $3 \mathrm{mg} /$ day for children 4-8 years; $6 \mathrm{mg} /$ day for children $9-13$ years; $9 \mathrm{mg}$ /day for adolescents $14-18$ years, and $11 \mathrm{mg} /$ day for adults $>19$ years (O'Neal and Zang, 2015). These findings are analogous with other published works (350 to $1.4 \times 10^{4} \mu \mathrm{g}$ $\mathrm{kg}^{-1}$ ) for $\mathrm{Mn}$ in gluten-free and gluten containing foods (Podio et al., 2013). If a person has a Fe deficient diet, there is an increased risk of Mn toxicity as Fe deficiency enhances the gastrointestinal absorption of Mn, leading to possible cognitive deficits (Higdon et al., 2014, FNB, 1997).

Molybdenum was detected in $78.7 \%$ of foods with a range of 250 and $6100 \mu \mathrm{g} \mathrm{kg}^{-1}$ with an overall $\overline{\mathrm{x}}$ of $1294 \mu \mathrm{g}$ $\mathrm{kg}^{-1}$. Gluten-free products (U.S. markets) ranged between 250 and $6100 \mathrm{\mu g} \mathrm{kg}^{-1}$, Asian products ranged from 350 to $2100 \mu \mathrm{g} \mathrm{kg}^{-1}$, and gluten containing foods ranged between 700 and $1050 \mu \mathrm{g} \mathrm{kg}^{-1}$. Data show that $9.5 \%$ of samples were $1 \sigma$ above the overall $\overline{\mathrm{x}}\left(2580 \mu \mathrm{g} \mathrm{kg}^{-1}\right)$ for pasta gluten-free foods (samples 2, 5, 6, 22). Molybdenum toxicity is relatively rare in humans as it functions as a co-factor in four Mo-dependent enzymes necessary for health (Higdon et al., 2014, O'Neal and Zang, 2015). Other studies have set a daily intake of 300 $\mu \mathrm{g}$ /day for children 1-3 years; $600 \mu \mathrm{g} /$ day for children $4-8$ years; $1.1 \mathrm{mg} /$ day for children $9-13$ years; $1.7 \mathrm{mg} / \mathrm{day}$ for adolescents $14-18$ years, and $2.0 \mathrm{mg}$ /day for adults $>19$ years (O'Neal and Zang, 2015, Suchowilska et al., 2012). Although the Institute of Medicine found little evidence of adverse health effects related to excess Mo consumption in healthy people, they have set a daily UIL at $300 \mu \mathrm{g} /$ day for children 1-3 years, $600 \mu \mathrm{g} /$ day for children 4-8 years, $1.1 \mathrm{mg} /$ day for children $9-13$ years, $1.7 \mathrm{mg} /$ day for adolescents $14-18$ years, and $2.0 \mathrm{mg} /$ day 
for adults $>19$ years (Higdon et al., 2014). Levels are within limits set in other studies (420 to $580 \mu \mathrm{g} \mathrm{kg}^{-1} \mathrm{Mo}$ ) for gluten-free and gluten containing foods.

Nickel was detected at 150 to $5000 \mu \mathrm{g} \mathrm{kg}^{-1}$ with an overall $\overline{\mathrm{x}}$ of $1757 \mu \mathrm{g} \mathrm{kg}^{-1}$. Gluten-free products from the U.S. ranged between 150 and $4350 \mu \mathrm{g} \mathrm{kg}^{-1}$, Asian foods ranged from $3004350 \mu \mathrm{g} \mathrm{kg}^{-1}$, and gluten containing foods ranged between 4950 and $5350 \mu \mathrm{g} \mathrm{kg}^{-1}$. In $14.3 \%$ of samples, Ni was $1 \sigma$ above the overall $\overline{\mathrm{x}}\left(1757 \mu \mathrm{g} \mathrm{kg}^{-1}\right)$ across a mix of pasta and flour food products (samples 5, 9, 14, 23, 41, 42). Additionally, four gluten containing pastas (samples $43-45,47$ ) were $1 \sigma$ above the overall $\bar{x}$. In the literature, Ni detected in foods is normally lower than $1000 \mu \mathrm{g} \mathrm{kg}^{-1}$ as described by Ekholm et al. (2007); placing these finding above acceptable ranges in 33\% of gluten-free foods and $60 \%$ of gluten containing foods. The risk of Ni toxicity is low due to its limited intestinal absorption according to ATSDR (2008).

Titanium ranged from 7000 to $3.1 \times 105 \mu \mathrm{g} \mathrm{kg}^{-1}$ with an overall $\overline{\mathrm{x}}$ of $5.53 \times 104 \mu \mathrm{g} \mathrm{kg}^{-1}$. Gluten-free products (U.S. market) ranged from 7000 and $2.17 \times 105 \mu \mathrm{g} \mathrm{kg}^{-1}$, Asian products ranged between 8350 and $3.1 \times 105 \mu \mathrm{g}$ $\mathrm{kg}^{-1}$, and gluten containing foods ranged between $1.03 \times 104$ and $3.62 \times 104 \mu \mathrm{g} \mathrm{kg}^{-1}$. Compared with other elements, Ti was found to be high and more in line with crustal metals (i.e. $\mathrm{Ca}, \mathrm{Mg}$ ) with $14.3 \%$ of the samples $(7,14,23,26,36,41) 1 \sigma$ above the overall $\bar{x}$ for gluten-free pastas and flours. Other authors have determined that the typical exposure to food-grade $\mathrm{TiO}_{2}$ in an average adult to be on the order of $1000 \mu \mathrm{g} \mathrm{kg}^{-1}$ per day (Weir et al., 2012); placing this data above the established norms in $100 \%$ of samples. It is important to note that Weir et al. (2012) stated there is an important difference between total $\mathrm{Ti}\left({ }_{\mathrm{T}} \mathrm{Ti}\right), \mathrm{TiCl}_{4}{ }^{\prime}$ and food-grade $\mathrm{TiO}_{2} \cdot \mathrm{Other}$ researchers have shown that $\mathrm{TiCl}_{4}$ is the harmful form of Ti; however, the forms of Ti found in foods are $\mathrm{TiO}_{2}$ MPs (micro-particles) and $\mathrm{TiO}_{2}$ NPs (nanoparticles) thus, no limit is specified in the literature at this time (ATSDR, 2008).

Zinc ranged from 5350 to $8.0 \times 104 \mu \mathrm{g} \mathrm{kg}^{-1}$ with an overall $\overline{\mathrm{x}}$ of $3.9 \times 104 \mu \mathrm{g} \mathrm{kg}^{-1}$ in analyzed foods. Gluten-free (U.S. market) ranged between 5750 and $8.0 \times 104 \mu \mathrm{g} \mathrm{kg}^{-1}$; Asian products ranged between 5350 and $3.7 \times 104$ $\mu \mathrm{g} \mathrm{kg}^{-1}$; while gluten containing foods ranged from $2.8 \times 104$ and $6.8 \times 104 \mu \mathrm{g} \mathrm{kg}^{-1}$. Zinc was also in line with crustal metals (i.e. $\mathrm{Ca}, \mathrm{Mg}$ ) with $23.8 \%$ (samples $5,6,9,11,14,15,22-24,28) 1 \sigma$ above the overall $\bar{x}(6.26 \mathrm{x}$ $104 \mu \mathrm{g} \mathrm{kg}^{-1}$ ) with sample 45 (gluten containing pasta) significantly greater than $1 \sigma$ of the overall $\overline{\mathrm{x}}$. Other studies have determined that the average $\mathrm{Zn}$ in foods range between 9400 and $5 \times 104 \mathrm{~g} \mathrm{~kg}^{-1}$ (Ertl and Coessler, 2018). It is known that $\mathrm{Zn}$ is an important trace element to the human diet and is therefore required as part of our food chain (Bermudez et al., 2011). The levels of $\mathrm{Zn}$ that can produce an adverse health effect are much higher than the Recommended Dietary Allowances (RDAs) of $11 \mathrm{mg} / \mathrm{day}$ for men and $8 \mathrm{mg} / \mathrm{day}$ for women (ATSDR, 2008). Likewise, data places $\mathrm{Zn}$ in the gluten-free foods above the established range in $35.7 \%$ in the gluten-free samples and $20 \%$ of gluten containing foods. Therefore, the levels of $\mathrm{Zn}$ that can produce an adverse health effect are much higher than the Recommended Dietary Allowances (RDAs) of $11 \mathrm{mg} / \mathrm{day}$ for men and $8 \mathrm{mg} / \mathrm{day}$ for women which this data is below (ATSDR, 2008).

\section{Conclusions}

This study produced similar results to those of Orecchio et al. $(2014,2015)$ where they evaluated trace elements in gluten-free foods across Italy. Most elements were detected in all samples with $\mathrm{Ca}, \mathrm{Fe}, \mathrm{Mg}$, Ti and $\mathrm{Zn}$ being those with the greatest $\overline{\mathrm{x}}$ concentrations across food products but, below harmful levels with a normal, healthy diet. Cadmium was detected $\left(0-600 \mu \mathrm{g} \mathrm{kg}^{-1}\right)$ in $96.8 \%$ of the U.S., $54.5 \%$ of Asian gluten-free foods, and in $100 \%$ of gluten containing foods, although all below action limits in the literature (2004). Cobalt was present in $48.4 \%$ of the U.S., 72.7\% of Asian gluten-free foods, and $40 \%$ of the gluten containing foods; $\mathrm{Cr}$ was detected in $54.8 \%$ of the U.S., $72.7 \%$ of Asian gluten-free foods, and $100 \%$ of the gluten containing products. Chromium in gluten-free foods was below reported averages of $799 \mu \mathrm{g} \mathrm{kg}^{-1}$ except in sample 39 and all of the gluten containing foods; however, even these levels are below the action limits reported by the WHO (2004). There was little difference in trace metal content observed between the pasta or flour products however, gluten containing food had higher levels of metals then those deemed gluten free.

It has been suggested that gluten-free foods may at times contain higher levels of metals than gluten containing foods (Orecchio et al., 2014, Thompson, 2000). This study found elevated trace metals were more commonly found in the gluten containing products, but at limits below WHO (2004) action levels. This is likely the product used for gluten free (i.e. rice) do not have an affinity to up-take metals as does other products such as wheat and barely. It is possible that low-level exposure to metal laden gluten-free and gluten containing foods, even at low levels, can lead to chronic toxicity with long-term consumption. Additional research is required to better understand the sources and pathways of trace elements in these foods. 


\section{Acknowledgments}

We would like to thank CSN student research assistants for their contribution to this project during the summer of 2018. Also, we would like to thanks the reviewers of this research whose time and expertise added great value to its overall presentation.

\section{Conflicts of Interest}

The authors declare no conflict of interest.

\section{Author Contributions}

Conceptualization, DBS, ACH, CJC; Methodology, statistics, writing, final review and editing, DBS, CJC, ACH, KWK, DJW; Laboratory task, tables, AAD and GMF; Funding acquisition, DBS.

\section{Funding}

This research was made possible by a grant from the National Institute of General Medical Sciences (GM103440) from the National Institutes of Health. This project's contents are solely the responsibility of the authors and do not necessarily represent the official views of NIH or the College of Southern Nevada.

\section{References}

Aziz, R. A., Rahim, S. A., Sahid, I., \& RaziIdris, W. M. (2015). Speciation and Availability of Heavy Metals On Serpentinized Paddy Soil and Paddy Tissue. Procedia - Social and Behavioral Sciences, 195, 1658-1665. http://doi.org/10.1016/j.sbspro.2015.06.235

Agency for Toxic Substances and Disease Registry (ATSDR) (2008). Relevance to Public Health. Atlanta, GA: Centers for Disease Control. Retrieved from https://www.atsdr.cdc.gov/az/a.html

Baker, A., Garner, M. C., Kimberley, K. W., Sims, D. B., Stordock, J. H., Taggart, R. P., \& Walton, D. J. (2018). Cyanide toxicity of freshly prepared smoothies and juices frequently consumed in the raw and natural food craze. European J Nutrition \& Food Safety, 8(4), 215-224. https://doi.org/10.9734/EJNFS/2018/44004

Basha, A. M., Yasovardhan, N., Satyanarayana, S. V., Subba, R. G. V., \& Kumar, A. V. (2014). Trace metals in vegetables and fruits cultivated around the surroundings of Tummalapalle uranium mining site, Andhra Pradesh, India. Toxicology Report, 1, 505-512. http://doi.org/10.1016/j.toxrep.2014.07.011

Bermudez, G., Jasan, R., Plá, R., \& Pignata, M. (2011). Heavy metal and trace element concentrations in wheat grains: assessment of potential non-carcinogenic health hazard through their consumption. J Hazard Mater, 193, 264-271. https://doi.org/10.1016/j.jhazmat.2011.07.058

Catassi, C., Bai, J. C., Bonaz, B., Bouma, G., Calabro, A., Carroccio, A., Castillejo, G., Ciacci, C., Cristofori, F., \& Dolinsek, J. (2013). Non-Celiac Gluten sensitivity: the new frontier of gluten related disorders. Nutrients, 5, 3839-3853. https://doi.org/10.3390/nu5103839

Clemente, J., Satou, K., \& Valiente, G. (2005). Reconstruction of phylogenetic relationships from metabolic pathways based on the enzyme hierarchy and the gene ontology. Genome Inform, 16, 45-55.

Curiel, J. A., Coda, R., Limitone, A., Katina, K., Raulio, M., Giuliani, G., Rizzello, C. G., \& Gobbetti, M. (2014). Manufacture and characterization of pasta made with wheat flour rendered gluten-free using fungal proteases and selected sourdough lactic acid bacteria. J. Cereal Sci., 59, 79-87. https://doi.org/10.1016/j.jcs.2013.09.011

Commission Regulation (EC) No 1881/2006 of 19 December (2006). Setting maximum levels for certain contaminants in foodstuffs. Off. J. Eur. Union L364: 5-24.

Ekholm, P., Reinivuo, H., Mattila, P., Pakkala, H., Koponen, J., Happonen, A., Hellström, J., \& Ovaskainen, M. (2007). Changes in the mineral and trace element contents of cereals, fruits and vegetables in Finland. $J$ Food Compost Anal, 20(6), 487-495. https://doi.org/10.1016/j.jfca.2007.02.007

Elli, L., Branchi, F., Tomba, C., Villa, D., Norsa, L., Ferretti, F., Roncoroni, L., \& Bardella, M. T. (2015). Diagnosis of gluten related disorders: Celiac disease, wheat allergy and non-celiac gluten sensitivity. World J Gastroenterol, 21(23), 7110-7119. https://doi.org/10.3748/wjg.v21.i23.7110

Ertl, K., \& Coessler, W. (2018). Grains, whole flour, white flour, and some final goods: an elemental comparison. European Food Research and Technology, 244, 2065-2075. https://doi.org/10.1007/s00217-018-3117-1

Finberg, L., Dweck, H. S., Holmes, F., Kretchmer, N., Mauer, A. M., Reynolds, J. W., Suskind, R. M., \& Hellerstein, S. (1986). Aluminum toxicity in infants and children. Pediatrics, 78(6), 1150-1154. 
Food and Nutrition Board (FNB), Institute of Medicine (1997). Dietary reference intakes for calcium, phosphorous, magnesium, vitamin D, and fluoride. National Academy Press, Washington, DC.

Han, S. J., Vaccari, S., Nedachi, T., Andersen, C. B., Kovacina, K. S., Roth, R. A., \& Conti, M. (2006). Protein kinase B/Akt phosphorylation of PDE3A and its role in mammalian oocyte maturation. EMBO J., 25, 5716-5725. https://doi.org/10.1038/sj.emboj.7601431

Higdon, J., Drake, V. J., \& Delage, B. (2014). Magnesium. Linus Pauling Institute. Oregon State University. Retrieved from https://lpi.oregonstate.edu/book/export/html/251

Howdle, P. D. (2003). Celiac (Coeliac) Disease Encyclopedia of Food Sciences and Nutrition, 2nd ed., 987-994. https://doi.org/10.1016/B0-12-227055-X/00266-2

Inaba K., Murakami, S., Suzuki, M., Nakagawa, A., Yamashita, E., Okada, K., \& Ito, K. (2006). Crystal structure of the DsbB=DsbA complex reveals a mechanism of disulfide bond generation. Cell, 127, 789-801. https://doi.org/10.1016/j.cell.2006.10.034

Jaishankar, M., Tseten, T., Anbalagan, N., Mathew, B. B., \& Beeregowda, K. N. (2014). Toxicity, mechanism and health effects of some heavy metals. Interdisciplinary Toxicology, 7(2), 60-72. https://doi.org/10.2478/intox-2014-0009

Kahn, C. M., \& Line, S. (Eds.). (2010a). Copper Poisoning. In: The Merck Veterinary Manual, $10^{\text {th }}$ edition. Whitehouse Station, NJ. Merck and Company, Inc.; pp. 2655-2657.

Kahn, C. M., \& Line, S. (Eds.). (2010b). Toxicities from Human Drugs. In: The Merck Veterinary Manual, $10^{\text {th }}$ edition. Whitehouse Station, NJ. Merck and Company, Inc.; pp. 2613-2614.

Kipp, M., Clarner, T., Dang, J., Copray, S., \& Beyer, C. (2009). The cuprizone animal model: new insights into an old story. Acta Neuropathol, 118, 723-736. https://doi.org/10.1007/s00401-009-0591-3

Kovalchuk, I., Kovalchuk, O., Arkhipov, A., \& Hohn, B. (1998). Transgenic plants are sensitive bioindicators of nuclear pollution caused by the Chernobyl accident. Nat Biotechnol, 16, 1054-1059. https://doi.org/10.1038/3505

Leyssens, L., Vinck, B., Van Der Straeten, C., Wuyts, F., \& Maes, L. (2017). Cobalt toxicity in humans-A review of the potential sources and systemic health effects. Toxicology, 387, 43-56. https://doi.org/10.1016/j.tox.2017.05.015

Loska, K., \& Wiechuya, D. (2003). Application of principle component analysis for the estimation of source of heavy metal contamination in surface sediments from the Rybnik reservoir. Chemosphere, 51, 723-733. http://doi.org/10.1016/S0045-6535(03)00187-5

Miedico, O., Iammarino, M., Tarallo, M., \& Chiaravalle, A. E. (2017). Application of inductively coupled plasma-mass spectrometry for trace elements characterization of equine meats. Intern. J. Food Properties. 20(12), 2888-2900. http://doi.org/10.1080/10942912.2016.1256304

Mertz, W. (Eds.). (1986). Trace elements in human and animal nutrition, 5th ed. New York, NY, Academic Press, pp. 418-420.

Millour, S., Noel, L., Chekri, R., Vastel, C., Kadar, A., Sirot, V., Leblanc, J. C., \& Guerin, T. (2012). Strontium, Silver, Tin, iron, tellurium, gallium, germanium, barium and vanadium levels in foodstuffs from the second French total diet study. J. Food Compos. Anal., 25, 108-129. http://doi.org/10.1016/j.jfca.2011.10.004

National Academy of Science (1973). Medical and Biological Effects of Environmental Pollution - Arsenic. Washington D.C.

Nicholson, F. A., Smith, S. R., Alloway, B. J., Carlton-Smith, C., \& Chambers, B. J. (2003). An inventory of heavy metals inputs to agricultural soils in England and Wales. Sci. Total Environ, 311, 205-219. https://doi.org/10.1016/S0048-9697(03)00139-6

Niewinski, M. M. (2008). Advances in celiac disease and gluten-free diet. J. Am. Diet. Assoc., 108, 661-672. https://doi.org/10.1016/j.jada.2008.01.011

O'Neal, S. L., \& Zheng, W. (2015). Manganese toxicity upon overexposure: a decade in review. Current Environmental Health Reports, 2(3), 315-328. https://doi.org/10.1007/s40572-015-0056-x

Orecchio, S., Amorello, D., Raso, M., Barreca, S., Lino, C., \& Gaudio, F. D. (2014). Determination of trace elements in gluten-free food for Celiac people by ICP-MS. Microchem. J., 116, 163-172.

http://doi.org/10.1016/j.microc.2014.04.011 
Orecchio, S., Amorello, D., Raso, M., Barreca, S., Lino, C., \& Gaudio, F. D. (2015). Determination of macro elements in gluten-free food for Celiac people by ICP-MS. Life Safety and Security, 3(9), 36-48.

Parra-Orobio, B. A., Donoso-Bravo, A., Ruiz-Sánchez, J. C., Valencia-Molina, K. J., \& Torres-Lozada, P. (2017). Effect of inoculum on the anaerobic digestion of food waste accounting for the concentration of trace elements. Waste Management, 71, 342-349. http://doi.org/10.1016/j.wasman.2017.09.040

Patel, A. M., \& Goldfarb, S. (2010). Got calcium? Welcome to the calcium-alkali syndrome. J American Society of Nephrology, 21, 1440-1443. https://doi.org/10.1681/ASN.2010030255

Podio, N., Baroni, M., Badini, R., Inga, M., Ostera, H., Cagnoni, M., Gautier, E., García, P., Hoogewerff, J., \& Wunderlin, D. (2013). Elemental and isotopic fingerprint of Argentinean wheat. Matching soil, water, and crop composition to differentiate provenance. J Agric Food Chem, 61(16), 3763-3773. https://doi.org/10.1021/jf305258r

Río, C. M. D., Font, R., Almela, C., \& Haro, A. D. (2002). Heavy metals and arsenic uptake by wild vegetation in the Guadiamar river area after the toxic spill of the Aznalcóllar mine. J Biotechnology, 98(1), 125-37. https://doi.org/10.1016/S0168-1656(02)00091-3

Reglero, M. M., Monsalve-González, L., Taggart, M. A., \& Mateo, R. (2008). Transfer of metals to plants and red deer in an old lead mining area in Spain. Sci. Total Environ., 406, 287-297. https://doi.org/10.1016/j.scitotenv.2008.06.001

Ross, A. C., Taylor, C. L., Yaktine, A. L., et al., (Eds.). (2011). Tolerable Upper Intake Levels: Calcium and Vitamin D. In: Dietary Reference Intakes for Calcium and Vitamin D. Washington DC. National Academy of Sciences; NIH Bookshelf ID: NBK56058.

Shugaba, A., Buba, F., Kolo, B. G., Nok, A. J., Ameh, D. A., et al., (2012). Uptake and Reduction of Hexavalent Chromium by Aspergillus niger and Aspergillus parasiticus. J Phylogenetics Evol Biol, 3, 119. https://doi.org/10.4172/2157-7463.1000119

Simonsen, L. O., Harbak, H., \& Bennekou, P. (2012). Cobalt metabolism and toxicology-a brief update. Sci Total Environment, 432, 210-215. https://doi.org/10.1016/j.scitotenv.2012.06.009

Suchowilska, E., Wiwart, M., Kandler, W., \& Krska, R. (2012). A comparison of macro- and microelement concentrations in the whole grain of four Triticum species. Plant Soil Environ, 58(3), 141-147. https://doi.org/10.17221/688/2011-PSE

Škrbic, B., Zivancev, J., \& Mrmoš, N. (2013). Concentrations of arsenic, cadmium and lead in selected foodstuffs from Serbian market basket: Estimated intake by the population from the Serbia. Food Chem. Toxicol., 58, 440-448. http://doi.org/10.1016/j.fct.2013.05.026

Takagi, Y., Nomizu, M., Ui-Tei, K., Tokushige, N., \& Hirohashi, S. (2004). Active sites in the carboxyl-terminal region of the laminin a chain in Drosophila neuronal cell spreading. Arch. Insect Biochem. Physiol., 56(4), 162-169. https://doi.org/10.1002/arch.20006

Tchounwou, P. B., Yedjou, C. G., Patlolla, A. K., \& Sutton, D. J. (2012). Heavy metals toxicity and the environment. EXS, 101, 133-164. https://doi.org/10.1007/978-3-7643-8340-4_6

Thompson, T. (1999). Thiamin, riboflavin, and niacin contents of the gluten-free diet: is there cause for concern? J Am. Diet. Assoc., 99, 858-862. https://doi.org/10.1016/S0002-8223(99)00205-9

Thompson, T. (2000). Folate, iron, and dietary fiber contents of the gluten-free diet. J Am. Diet. Assoc., 100, 1389-1396. https://doi.org/10.1016/S0002-8223(00)00386-2

Thompson, T., Dennis, M., Higgins, L. A., Lees, A. R., \& Sharrett, M. K. (2005). Gluten-free diet survey: are Americans with celiac disease consuming recommended amounts of fibre, iron, calcium and grain foods? $J$ Hum. Nutr. Dietetics, 18, 163-169. https://doi.org/10.1111/j.1365-277X.2005.00607.x

USEPA (1997). SW-846, Test Methods for Evaluating Solids and Wastes - Physical/Chemical Methods, US Environmental Protection Agency (CD), Washington DC.

Vahter, M., Åkesson, A., Lidén, C., Ceccatelli, S., \& Berglund, M. (2007). Gender differences in the disposition and toxicity of metals. Environmental Research, 104(1), 85-95. https://doi.org/10.1016/j.envres.2006.08.003

Vazquez, A. L., Masamoto, K., \& Kim, S. G. (2008). Dynamics of oxygen delivery and consumption during evoked neural stimulation using a compartment model and $\mathrm{CBF}$ and tissue $\mathrm{P}(\mathrm{O} 2)$ measurements. Neuroimage, 42, 49-59. https://doi.org/10.1016/j.neuroimage.2008.04.024 
Wang, Y., Chen, X., \& Xiang, C. B. (2007). Stomatal density and bio-water saving. Journal of Integrative Plant Biology, 49, 1435-1444. https://doi.org/10.1111/j.1672-9072.2007.00554.X

Weir, A., Westerhoff, P., Fabricius, L., Hristovskill, K., \& Goetz, N. V. (2012). Titanium Dioxide Nanoparticles in Food and Personal Care Products. Environ. Sci. Technol., 46(4), 2242-2250. http://doi.org/10.1021/es204168d

World Health Organization (WHO) (2004). Changing history. Geneva. 1-96.

Yamagami, T., Ezaki, T., Moriguchi, J., Fukui, Y., Okamoto, S., Ukai, H., Sakurai, H., Aoshima, K., \& Ikeda, M. (2006). Low-level cadmium exposure in Toyama Cuty and its surroundings in Toyama prefecture, Japan, with references to possible contribution of shellfish intake to increase urinary cadmium levels. Sci. T. Environ., 362(1-3), 56-57. https://doi.org/10.1016/j.scitotenv.2005.05.043

Yokel, R. A., Urbas, A. A., Lodder, R. A., Selegue, J. P., \& Florence, R. L. (2005). Al-containing acidic and basic sodium aluminum phosphate Preparation and use in studies of oral aluminum bioavailability from foods utilizing 26Al as an aluminum tracer. Nuclear Instrum. Meth. Phys. Res. B, 229, 471-478.

https://doi.org/10.1016/j.nimb.2004.12.130

\section{Copyrights}

Copyright for this article is retained by the author(s), with first publication rights granted to the journal.

This is an open-access article distributed under the terms and conditions of the Creative Commons Attribution license (http://creativecommons.org/licenses/by/4.0/). 